\title{
Incorporating Pragmatics in English Language Teaching: To What Extent Do EFL Course Books Address Speech Acts?
}

\author{
Yasemin Aksoyalp (Corresponding author) \\ Adam Mickiewicz University, Faculty of English, Department of Pragmatics of English \\ Niepodległości 4, 61-874 Poznań, Poland \\ E-mail: yaksoyalp@gmail.com \\ Tugba Elif Toprak \\ Gazi University, Faculty of Education, Department of English Language Teaching \\ Teknikokullar, 06500, Ankara, Turkey \\ E-mail: tugbaeliftoprak@gmail.com
}

Received: 12-08-2014

Accepted: 19-10-2014

Published: 01-03-2015

doi:10.7575/aiac.ijalel.v.4n.2p.125

URL: http://dx.doi.org/10.7575/aiac.ijalel.v.4n.2p.125

\begin{abstract}
Investigating the presence and presentation of speech acts in course books may be significant in an EFL (English as a Foreign Language) environment since in most cases, students rely on them for pragmatic input. Though a large body of research has dealt with the speech acts, relatively little research has been conducted to examine the speech acts in English course books. To fill in this gap, this study aimed to investigate how complaints, apologies and suggestions were presented in EFL course books. To this end, a content analysis on 17 course books of different language proficiency levels (i.e. from beginner to advanced) was conducted to find out (i) whether the course books included the aforementioned speech acts (ii) the range and frequencies of linguistic strategies used to perform these speech acts and (iii) whether their frequency showed variation across all proficiency levels. The findings have clear implications for course book writers, publishers and language teachers. The findings are presented and implications are made. Keywords: speech acts, course books, EFL, proficiency level
\end{abstract}

\section{Introduction}

The period between the 1880s and 1980s witnessed a remarkable change in language pedagogy. This endeavour to achieve better practices paved the way for a paradigm shift from a structural view of language to a functional and finally a communicative view of language. In parallel with these developments, the concept of 'competent language user' has been redefined by Kramsch (1988, p. 27) as:

The characteristic of a 'competent language user' [is] not the ability to speak and write according to the rules of the academy and the social etiquette of one social group, but the adaptability to select those forms of accuracy and those forms of appropriateness that are called for in a given social context of use.

As can be inferred from this definition, not only the mastery of grammatical, lexical, phonological and morphological structures but also the knowledge of context and sociocultural norms are needed to be considered as a competent language user. This view leads us to two notions: 'pragmatics' and 'pragmatic competence'. In accordance with the context of the present study, the term 'pragmatics' is defined as "a branch of linguistics that focuses on the use of language in social contexts and the ways in which people produce and comprehend meanings through language" (Kecskes, 2014, p. 8). 'Pragmatic competence', which is, in view of Bachman (1990), a significant component of communicative competence involves the knowledge that learners employ in order to perform a speech act successfully when interacting with native speakers of the target language in a particular cultural and social setting. In other words, pragmatic competence encompasses the knowledge of the linguistic resources required to realize a speech act and of socio-cultural constraints which govern the use of these linguistic resources (Bachman, 1990). Taking the Bachman's point of view into account, it is possible to indicate that developing pragmatic competence is one of the crucial goals to be attained by language learners to become communicatively competent in the target language.

Speech acts which are considered as an essential component of pragmatic competence can be defined as the actions performed by means of utterances. To put it in another way, speech acts are the core units of human communication. Complaints, apologies and suggestions, which are in the scope of the present study, are among examples of speech acts. Although speech acts exist in all languages, the linguistic realizations and frequencies of them are culture-bound. Speech acts mirror the basic cultural values and social norms of a language and society and reflect language use in a specific speech community. So far, to uncover the nature and linguistic realizations of speech acts across different languages and contexts, numerous studies have been conducted and these studies have focused on specific speech acts, such as apologies (Cohen and Olshtain, 1981; Blum-Kulka and Olshtain, 1984), suggestions (Banerjee and Carrell, 
1988; Martínez-Flor 2005) and complaints (Boxer, and Pickering, 1995). Despite prolific research on speech acts in various languages, little research has addressed the use of speech acts in course books. Few attempts known to us belong to Boxer and Pickering (1995), who examined indirect complaints, only in seven English course books and Philips' (1993) survey of polite requests in French course books. Taking the limited nature of these studies into account, it could be inferred that this issue deserves scholarly attention.

An investigation into the pragmatic dimension of course books used especially in an EFL context is vital since pragmatic knowledge can be conveyed mostly by means of course books. Learners in an ESL environment have more opportunity to acquire appropriate pragmatic routines; whereas, in an EFL environment the learners largely depend on course books to be exposed to the same pragmatic input. Moreover, it is a common observation that language teachers often tend to fall short of meta-pragmatic awareness and pragmatic knowledge. Given the crucial function of course books in presenting pragmatic input, it is quite surprising that there remains a lot to investigate in this field as attempts to explore this issue is relatively scarce. Especially, the difficulty of pragmatic realization and face-threatening nature of complaints, apologies and suggestions call for their exploration in a course book context.

Hence, the present study aims to fill in this gap by investigating the presentation and frequencies of complaints, apologies and suggestions by analyzing 17 English course books prepared by leading international publishers used at Schools of English of different universities in an EFL setting, Turkey, by means of content analysis technique. More specifically, it sets out to explore (i) whether the analyzed course books included the speech acts of complaints, apologies and suggestions (ii) the range and frequencies of linguistic strategies used to perform these speech acts and (iii) whether the frequency of speech acts varied across all proficiency levels of course books. This research intends to contribute to the research agenda which received relatively scant attention within the context of the present study.

\section{Methodology}

17 EFL course books of different language proficiency levels (beginner, elementary, pre-intermediate, intermediate, upper intermediate and advanced) were used as the data sources to identify the complaint, suggestion and apology situations (see Appendix A). Two criteria were employed for identifying above mentioned speech acts. These were (i) the occurrence of speech acts formulas and (ii) the exclusion of grammar sections from the scope of the analysis. Three different types of taxonomies were utilized for the analysis and these were developed by Demeter (2006) for apologies, Meinl (2010) for complaints and Martínez-Flor (2005) for suggestions. Each taxonomy, along with its strategies, is presented below in detail.

\section{Complaints}

According to Brown and Levinson's (1987) politeness theory, complaints are face-threatening acts expressing complainers' anger about a committed offence. In terms of their distinction between positive and negative face, complaints are threats to the hearer's positive face, as they go against a person's desire to be appreciated, approved of, and respected. The taxonomy of complaints is composed of eight linguistic realization strategies as explained below (Meinl 2010).

\section{Strategy 1: Expression of disappointment}

Complainers tend to express their disappointment about the problem, focus on their own feelings and implicitly put the blame on the complainee.

\section{Strategy 2: Expression of anger or annoyance}

Complainers tend to demonstrate their anger or annoyance towards the state of affairs and concentrate on their own feelings as in Strategy 1.

Strategy 3: Explicit complaint

Complainers explicitly mention the offensive act but avoid judging the addressee's behaviour and instigating any sanctions.

Strategy 4: Negative judgment

Similar to Strategy 3, complainers mention the offensive act however, they hold the complainee responsible.

Strategy 5: Drawing one's own conclusion

In strategy 5 , the complainers draw a conclusion for their future action.

Strategy 6: Warning others

Complainers employing Strategy 6 explicitly warn the other people against the complainee.

Strategy 7: Threat

In this case complainers aim at stronger sanctions than only worsening the complainee's reputation, they may threaten the addressee with higher authorities.

Strategy 8: Insult

In Strategy 8, complainers explicitly condemn the accused people and insult them. 


\section{Apologies}

Apology is one of the remedial devices to reestablish social harmony among interactants. By apologizing, an offender takes responsibility for an offensive act and expresses regret for an undesirable event. According to Brown and Levinson (1987, p. 70), apologies express negative politeness. They signal the speaker's awareness of putting an imposition on the hearer's negative face thus, limiting hearer's freedom of action in some way.

1. Illocutionary Force Indicating Device (IFID): The explicit speech act expressing an apology as in 'I am sorry'.

2. Intensified IFID: This strategy refers to an element that shows the degree of the intensity of the IFID is also introduced as in "I am very sorry".

3. Providing a justification: The offender tries to give an explanation of why the situation that required the apology took place.

4. Acknowledgment of responsibility: The offender takes responsibility by explicitly admitting that he is guilty.

5. Offer of repair: This strategy is usually used to offer a compensation for the physical or moral damage that the speaker has caused.

6. Blaming someone else or denying of responsibility: The offender mostly tries to place the blame on someone or something else either overtly - by blaming somebody or something - or covertly, by denying responsibility.

7. Promise of non-recurrence: The speaker promises not to repeat the action that requires the apology.

8. Attacking the complainer: The speaker attempts to save face by confronting the listener rather than apologizing.

9. Pleading for understanding: The speaker tries to save face by appealing to the understanding of the listener.

\section{Suggestions}

Suggestions are considered to be in the group of directive speech acts in which the speaker's aim is to get the hearer to commit him/herself to some future course of action. In a suggestion, the speaker assumes that the future action will be for the benefit of the hearer.

Brown and Levinson (1987) and Banerjee and Carrell (1988) argue that suggestions are regarded as face threatening acts since the speaker in some way intrudes into the hearer's world by performing an act that concerns what the hearer should do. This way, suggestions can be deemed as an imposition upon the hearer by affronting his/her negative face.

1. Direct strategies: Direct strategies are realized in four ways: a) performative verb as in 'I suggest that you...', b) noun of suggestion as in 'My suggestion would be..', c) imperatives as in 'Try using...” and d) negative imperative as in 'Don't try to...'.

2. Conventionalized forms: This group of suggestions are divided into five sub-strategies which are a) interrogative forms as in 'Why don't you..?', b) possibility as in 'You can...', c) should as in 'You should...', d) need as in 'You need to...' and e)conditional as in 'If I were you, I would...'.

3. Indirect Strategies: This group of suggestions are classified into three parts:

a) impersonal as in 'It might be better to...' b) hints as in 'I've heard that...'

b) inclusive we as in 'Let's...' and d) obligation as in 'You must...'.

At first, a pilot analysis on three course books was carried out to see whether aforementioned taxonomies would cover the situations in a pragmatically appropriate way, that is; each instance could be placed into categories and their subcategories. When it was concluded that the taxonomies functioned well, further analysis was conducted by using these taxonomies. 17 English course books were analysed twice by each researcher, which means that one course book was scrutinized four times altogether. A suitable type of strategy and its sub-category was assigned to each instance detected. To illustrate; the instance "How about a music show on Friday evening?" was categorized as a suggestion and it was inferred that this suggestion could be included in "conventionalized forms", one of the sub-categories of suggestion realized by the strategy of interrogative forms. Stated differently, for each instance identified, a three-step placement was carried out. The percentage of interrater agreement ranged from $95 \%$ to $100 \%$. Few differences in the ratings were easily resolved by re-examining the situation.

\section{Results and Discussion}

This section provides information related to the results obtained from the analysis of the course books. Overall frequencies and types of speech act strategies in total corpus could be found in Appendix 2. Below, Tables 1 and 2 present the types of speech act strategies and their frequencies at beginner and elementary levels. 
Table 1. Distribution of Speech Act Strategies at Beginner Level

\begin{tabular}{ccc}
\hline Speech act strategy & Frequency & Speech act type \\
\hline Explicit complaint & 53 & Complaint \\
IFID & 26 & Apology \\
Interrogative & 5 & Suggestion \\
Insult & 4 & Complaint \\
Intensified IFID & 3 & Apology \\
Inclusive we & 3 & Suggestion \\
Possibility & 2 & Suggestion \\
Justification & 1 & Apology \\
Imperative & 1 & Suggestion \\
Should & 1 & Suggestion \\
Anger & 1 & Complaint \\
Total & 100 & \\
\hline
\end{tabular}

Table 1 displays that the most frequent strategies were explicit complaints (53 instances) and IFID (26 instances). Other types of strategies such as intensified IFID (3 instances), possibility (2 instances), justification (1 instance), imperative (1 instance), interrogative ( 5 instances), should ( 1 instance), inclusive we (3 instances), anger (1 instance) and insult (4 instances) were also detected; however, they were scarce in number.

Table 2. Distribution of Speech Act Strategies at Elementary Level

\begin{tabular}{ccc}
\hline Speech act strategy & Frequency & Speech act type \\
\hline Inclusive we & 22 & Suggestion \\
IFID & 20 & Apology \\
Interrogative & 16 & Suggestion \\
Imperative & 11 & Suggestion \\
Should & 4 & Suggestion \\
Explicit complaint & 3 & Complaint \\
Intensified IFID & 2 & Apology \\
Disappointment & 1 & Complaint \\
Possibility & 1 & Suggestion \\
Total & 80 & \\
\hline
\end{tabular}

When we examine the results with regard to elementary level in Table 2, it could be said that the frequencies of strategies preferred seemed to be higher when compared to the beginner level. Though the number of the strategies used remained almost the same, the frequencies showed an increase as in inclusive we (22 instances), IFID (20 instances), interrogative (16 instances) and imperative (11 instances). Results related to pre-intermediate and intermediate levels are presented below.

Table 3. Distribution of Speech Act Strategies at Pre-intermediate Level

\begin{tabular}{ccc}
\hline Speech act strategy & Frequency & Speech act type \\
\hline Inclusive we & 14 & Suggestion \\
IFID & 13 & Apology \\
Explicit Complaint & 12 & Complaint \\
Interrogative & 10 & Suggestion \\
Intensified IFID & 3 & Apology \\
Should & 2 & Suggestion \\
Disappointment & 1 & Complaint \\
Impersonal & 1 & Suggestion \\
Total & 56 & \\
\hline
\end{tabular}

Table 3 displays that the most frequent strategies were inclusive we (14 instances), IFID (13 instances), explicit complaint (12 instances) and interrogative (10 instances) respectively. Different types of strategies (i.e. should, impersonal, intensified IFID and disappointment) were also detected; however, they were limited in number. 


\begin{tabular}{ccc}
\hline Speech act strategy & Frequency & Speech act type \\
\hline Imperative & 26 & Suggestion \\
Interrogative & 14 & Suggestion \\
IFID & 14 & Apology \\
Explicit complaint & 11 & Complaint \\
Inclusive we & 8 & Suggestion \\
Should & 4 & Suggestion \\
Intensified IFID & 3 & Apology \\
Negative judgement & 2 & Complaint \\
Justification & 1 & Apology \\
Possibility & 1 & Apology \\
Total & 84 & \\
\hline
\end{tabular}

When it comes to intermediate level, Table 4 demonstrates that the range became wider and the frequencies of strategies employed showed an increase, as in imperative (26 instances), IFID and interrogative (both 14 instances).

Table 5. Distribution of Speech Act Strategies at Upper-intermediate Level

\begin{tabular}{ccc}
\hline Speech act strategy & Frequency & Speech act type \\
\hline Explicit complaint & 47 & Complaint \\
Imperative & 36 & Suggestion \\
Negative judgement & 20 & Complaint \\
IFID & 12 & Apology \\
Disappointment & 9 & Complaint \\
Anger & 8 & Apology \\
Should & 6 & Suggestion \\
Interrogative & 5 & Suggestion \\
Inclusive we & 3 & Suggestion \\
Justification & 3 & Apology \\
Pleading for understanding & 2 & Apology \\
Possibility & 2 & Suggestion \\
Impersonal & 1 & Suggestion \\
Threat & 1 & Complaint \\
Insult & 1 & Apology \\
Antensified IFID & 1 & Complaint \\
Total & 1 & Apology \\
\hline
\end{tabular}

The results demonstrated in Table 5 indicated that the most frequent strategies were explicit complaint (47 instances), imperative (36 instances) and negative judgment (20 instances).

Table 6. Distribution of Speech Act Strategies at Advanced Level

\begin{tabular}{ccc}
\hline Speech act strategy & Frequency & Speech act type \\
\hline Explicit complaint & 65 & Complaint \\
Imperative & 47 & Suggestion \\
Negative judgement & 20 & Complaint \\
IFID & 10 & Apology \\
Obligation & 2 & Suggestion \\
Anger & 2 & Complaint \\
Possibility & 2 & Suggestion
\end{tabular}




$\begin{array}{ccl}\text { Impersonal } & 2 & \text { Suggestion } \\ \text { Performative } & 1 & \text { Suggestion } \\ \text { Justification } & 1 & \text { Apology } \\ \text { Inclusive we } & 10 & \text { Suggestions } \\ \text { Should } & 8 & \text { Suggestion } \\ \text { Negative imperative } & 5 & \text { Suggestion } \\ \text { Disappointment } & 5 & \text { Complaint } \\ \text { Need } & 5 & \text { Suggestion } \\ \text { Interrogative } & 4 & \text { Suggestion } \\ \text { Warning } & 3 & \text { Complaint } \\ \text { Insult } & 2 & \text { Complaint } \\ \text { Intensified IFID } & 2 & \text { Apology } \\ \text { Total } & 196 & \end{array}$

Compared to the other proficiency levels, it could be said that these two levels included a wider range of strategies employed at a higher frequency. New types of strategies such as lack of responsibility, pleading for understanding, threat, insult and warning were identified, which were not present at lower levels.

The results revealed that there seemed to be a close link between the proficiency level of the course books analysed and the complexity, range and frequency of the speech act strategies presented to the language learners. This is quite reasonable, in that there is a great deal of evidence in the relevant literature which lends support to the argument that there is a positive correlation between overall linguistic proficiency and pragmatic competence of the language learners (Rose, 2000). The findings of the present study also indicated that the course books' repertoire of speech act strategies expanded with their increasing proficiency level.

This relationship between the proficiency level of the course books analysed and the complexity of the linguistic realization of speech acts could be observed in the content presented. For instance; at the elementary level a direct complaint was performed via the following simple utterance: 'You shouldn't go to that restaurant on your birthday. The food is really bad' while at the advanced level the complexity level of the complaints increased. This change could be seen in a situation in which a doctor complains about the laziness of the nurses as: 'There is nothing more upsetting than seeing patients suffer because of basic laziness and incompetence. On each shift, I find myself constantly having to check and check again to ensure the nurses caring for my patients do their job properly!' In another situation a customer who was not satisfied with the service given at a hotel complained to the person in charge by saying 'According to your website, the hotel where we stayed was going to give us an evening entertainment program, which was described as being varied and fun-packed. Unfortunately, this was not the case and it left us and the other guests feeling extremely dissatisfied.' This complexity was detected in other two speech acts as well. For instance; at the beginning level, a student -late for a class- apologizes to his teacher by saying only 'Sorry' whereas a professor who could not attend a meeting expresses his apologies by saying 'Sorry, but I won't be able to make it this year as I have already got something on'. As illustrated, here the interlocutor not only performs the speech act of apology but also provides a justification for not committing the act of participation. When it comes to the speech act of suggestion, the situation does not differ from the other cases. In an upper-intermediate level course book a mother addresses her child as 'Why don't you let him help open your other presents?' On the contrary, at the beginning level suggestions are restricted to the uses such as 'Let's play tennis this weekend', 'OK, Let's go'.

Furthermore, the increase in the range and frequency of complaint strategies found in the course books also hinted that the proficiency level of the course books might be deemed as a significant variable in determining the amount of pragmatic complexity reflected in the course books. For instance; the dramatic rise in the frequency of explicit complaint, one of the strategies used to realize complaining, suggested that pragmatic competence and language proficiency might be seen as interrelated. Due to its face-threatening nature and making complainers vulnerable to how the others react, complaint is a speech act which requires a certain amount of delicacy and implicitness thus resulting in an extending sequence. To illustrate, while the act of complaining about an aching back is realized via the utterance 'My lower back aches a lot' (Language Leader-pre intermediate), the same speech act is performed as 'My husband is as stubborn as a mule. He refuses to go to the doctor about his bad back' (New English File-Advanced). Here attention should be paid to the use of idiomatic expression 'as stubborn as a mule' since idioms generally emerge as the proficiency level increases.

Likewise, in lower level course books (i.e. beginner, elementary, pre-intermediate levels) routine formulas such as 'Sorry', 'I am very sorry', and 'I am so sorry' are preferred to express apologies whereas these formulaic utterances are replaced by more linguistically complex strategies like accepting responsibility in higher level course books. This can be observed in a situation where a Chinese mother, living in the USA, holds herself responsible for inappropriate manners of her daughter in saying "It is my fault she is this way. I wanted my children to have the best combination: American circumstances and Chinese character. 'How could I know these two things do not mix?' (New English Fileadvanced level). As Kasper and Rose (2002) propose, the acquisition of L2 apology strategies may start from the 
formulaic stage, in which one acquires the routine formula expressing regret (i.e. 'I'm sorry/very sorry') first and then with increasing proficiency level this formulaic expression is combined with far more complex linguistic structures. The appearance of such linguistic structures (i.e. speech act strategies) as exemplified above complies with the linguistic and specifically pragmatic developmental stages of language learners.

Though the findings of the present study suggested that there was a positive correlation between the range and frequency of speech act strategies and the levels of the course books and these strategies were embedded in the content, we need to be sceptical about their adequacy. These findings were in line with the Olshtain and Cohen's study (1990), in which they found that speech act strategies were simplistically presented. For instance, quite similar to the findings obtained in the present study, Olshtain and Cohen (1990) also concluded that the simplest forms of apology such as 'Sorry', 'I'm sorry' and 'I am very sorry' were emphasized. This 'simplicity and generality' as Olshtain and Cohen (1990) call it, might derive from the absence of empirical research to draw upon and researches' relying on their intuitions while writing course books. It has been evidenced that most textbooks and other written manuals fail to supply a sufficient amount of pragmatic input, as they tend to illustrate an artificial and decontextualised use of the different pragmatic aspects. Besides this, course books examined are often deprived of natural conversational models which exemplify the real use of language (Bardovi-Harlig et al., 1991; Boxer and Pickering 1995; Martínez-Flor, 2005).

\section{Conclusion}

The purpose of the present study was to examine whether the course books in an EFL context included the speech acts of complaint, apology and suggestion. Furthermore, the range and frequencies of the linguistic strategies used to perform these speech acts and their variations across different language proficiency levels were also investigated. For the purpose of this investigation, 17 English course books of different language proficiency levels published by leading international publishers were analysed by using the content analysis technique.

The findings of the study demonstrated that the three speech acts in question -complaints, apologies and suggestionswere present in the course books analysed, though their linguistic realizations and complexity varied. To put it in another way, the range and frequency of strategies of speech acts increased as the proficiency level of the course books increased. For instance, an explicit complaint was realized in a linguistically more complex and detailed way in an advanced level course book while the same strategy was realized via a simple utterance at the elementary level. Although the speech acts in question were present at all levels of course books with varying complexity and frequency, the findings of the study pointed out that speech acts received limited attention when compared to other components of language such as grammar units, phonology, spelling etc.

Though the main motivation of this research was to examine the presence and presentation of the speech acts of complaints, apologies and suggestions in a novel context -text books- the findings had clear implications for the inclusion of speech acts in teaching-learning process. Since pragmatic competence may not develop in parallel with EFL learners' grammatical development (Bardovi-Harlig and Dörnyei, 1998; Bardovi-Harlig, 1999), pragmatic failures can be detected even in the comprehension and production of advanced language learners' communicative acts (BlumKulka et al., 1989). Such pragmatic deficits call for a specific emphasis that needs to be given to help learners develop pragmatic competence in the target language (i.e. English). This is also confirmed by Bardovi-Harlig, Mahan-Taylor, and Reynolds (1991) in their following contention:

When we approach the language class as an opportunity for learners to expand their communication across cultural boundaries, we, as teachers, have the responsibility to equip them with not only the structural aspects of the language, but with the pragmatics as well: more simply, the right words to say at the proper time. (pp. 13-14)

In line with the argument cited above, classroom-based empirical studies conducted by researchers (see for example, Koike and Pearson, 2005, Kasper, 2001; Alcon-Soler, 2005; Wishnoff, 2000, among many others) have highlighted the importance of incorporating pragmatics into pedagogical practices through pragmatic-awareness raising activities and investigated the efficacy of explicit teaching of pragmatics (Ishihara, 2007; Jernigan, 2008; Koike \& Pearson, 2005). In doing so, the aim is to "empower[s] students to experience and experiment with the language at a deeper level, and thereby to participate in the purpose of language communication, rather than just words" (Bardovi-Harlig et al., 1991, pp. 13-14).

Additionally, the findings suggested that pragmatic knowledge does not receive the attention it deserves from material developers and course book writers, hence should be devoted more attention. In order to refrain from making pragmatics a marginal aspect of target language instruction, the present study suggests that sections which aim to foster language learners' pragmatic competence could be included in course books. Furthermore, target pragmatic input needs to be given in a more authentic and contextualized way. Taking the language learners' level of linguistic proficiency into account, learners' exposure to the target pragmatic information could be supplemented by natural conversational models. It would be advisable for material developers and course books writers to integrate different types of activities for developing pragmatic competence with the content through awareness-raising activities and opportunities for communicative practice. 
The present study attempted to investigate the presence and linguistic realizations of suggestion, apology and complaint speech acts in course books which have received scarce scholarly attention. However, an analysis aiming at a larger corpus would be more revealing and would provide more generalizable results.

\section{References}

Alcon-Soler, A. (2005). Does instruction work for learning pragmatics in the EFL context? System, 33, 417-435.

Bachman, L. F. (1990). Fundamental considerations in language teaching. Oxford: Oxford University Press.

Banerjee, J., \& Carrell, P. (1988). Tuck in your shirt, you squid: suggestions in ESL. Language Learning, 38, 313-364.

Bardovi-Harlig, K., Hartford, B. S., Mahan-Taylor, R., Morgan, M. J., \& Reynolds, D.W. (1991). Developing pragmatic awareness: closing the conversation. ELT Journal, 45, 4-15.

Bardovi-Harlig, K., \& Dörnyei, Z. (1998). Do language learners recognise pragmatic violations? Pragmatic versus grammatical awareness in instructed L2 learning. TESOL Quarterly, 32(2), 233-259.

Blum-Kulka, S., \& Olshtain, E. (1984). Requests and apologies: a cross-cultural study of speech-act realization patterns (CCSARP). Applied Linguistics, 5(3), 196-213.

Blum-Kulka, S. House, J., \& Kasper, G. (Eds.), (1989). Cross-cultural pragmatics: requests and apologies. Norwood: Ablex.

Boxer, D., \& Pickering, L. (1995). Problems in the presentation of speech acts in ELT materials: The case of complaints. ELT Journal, 49(1), 44-58.

Brown, P. L., \& Levinson, S. (1987). Politeness some universals in language use. Cambridge: Cambridge University Press.

Cohen, A. D., \& Olshtain, E. (1981). Developing a measure of socio-cultural competence: the case of apology. Language Learning, 31(1), 113-134.

Demeter, G. (2006). A pragmatic study of apology strategies in Romanian. Unpublished master's thesis, North University, Romania.

Ishihara, N. (2007). Web-based curriculum for pragmatics instruction in Japanese as a foreign language: An explicit awareness-raising approach. Language Awareness, 16(1), 21-40.

Jernigan, J. (2008). Instruction and developing second language pragmatic competence: An Investigation into the efficacy of output. Unpublished doctoral dissertation, Florida State University, Tallahassee, FL.

Kasper, G. (2001). Four perspectives on L2 pragmatic development. Applied Linguistics, 22(4), 502-530.

Kasper, G., \& Rose, K. R. (2002). Pragmatic development in a second language. Oxford: Blackwell.

Kecskes, I. (2014). Intercultural Pragmatics. Oxford: Oxford University Press.

Koike, D., \& Pearson, L. (2005). The effect of instruction and feedback in the development of pragmatic competence. System, 33, 481-501.

Kramsch, C. (1988). The cultural discourse of foreign language textbooks. In A. Singerman (Ed.), Towards a new integration of language and culture (pp. 63-68). Middlebury, VT: Northeast Conference.

Martínez-Flor, A. (2005). A theoretical review of the speech act of suggesting: towards a taxonomy for its use in FLT. Revista Alicantina de Estudios Ingleses, 18, 167-187.

Meinl, E. M. (2010). Electronic complaints: an empirical study on British English and German complaints on eBay. Unpublished doctoral dissertation, University of Bonn, Germany.

Olshtain, E., \& Cohen, A. (1990). The learning of complex speech act behaviour. TESL Canada Journal, 7(2), 45-65.

Philips, E. M. (1993). Polite requests: second language textbooks and learners of French. Foreign Language Annals, 26(3), 372-381.

Rose, K. (2000). An exploratory cross-sectional study of interlanguage pragmatic development. Studies in Second Language Acquisition, 22, 27-67.

Wishnoff, J. (2000). Hedging your bets: L2 learners' acquisition of pragmatic devices in academic writing and computer mediated discourse. Second Language Studies, 19(1), 119-148. 
Detailed information about the course books in the corpus

Name of the course book

New English File

New English File

New English File

New English File

New English File

New Headway

New Headway

New Headway

New Headway

Language Leader

Language Leader

Language Leader

Language Leader

Language Leader

Top Notch 1

Top Notch 2

Top Notch 3

\section{Level of the course book}

Publisher

Oxford University Press

Oxford University Press

Elementary

Oxford University Press

Oxford University Press

Upper Intermediate

Oxford University Press

Oxford University Press

Beginner

Oxford University Press

Upper Intermediate

Oxford University Press

Advanced

Pearson Longman

Beginner

Pearson Longman

Elementary

Pearson Longman

Intermediate

Pearson Longman

Upper Intermediate

Pearson Longman

Advanced

Pearson Longman

Beginner

Pearson Longman

Elementary

Pearson Longman

Intermediate

Pearson Longman

\section{Appendix B}

Frequencies and types of speech act strategies in total corpus*

\begin{tabular}{ccc}
\hline Speech act strategy & Frequency & Speech act type \\
\hline Explicit complaint & 191 & Complaint \\
Imperative & 121 & Suggestion \\
IFID & 95 & Apology \\
Inclusive we & 60 & Suggestion \\
Interrogative & 54 & Suggestion \\
Negative judgement & 42 & Complaint \\
Should & 25 & Suggestion \\
Disappointment & 16 & Complaint \\
Intensified IFID & 14 & Apology \\
Anger & 11 & Complaint \\
Possibility & 8 & Suggestion \\
Insult & 7 & Complaint \\
Justification & 6 & Apology \\
Negative imperative & 5 & Suggestion \\
Need & 5 & Suggestion \\
Impersonal & 4 & Suggestion \\
Warning & 3 & Complaint \\
Obligation & 2 & Apology \\
Threat & 2 & Suggestion \\
Pleading for understanding & 1 & Complaint \\
Performative & 1 & Apology \\
Total & 1 & Suggestion \\
Acknowledgement of responsibility & 674 &
\end{tabular}

Note* : 674 speech act strategies were detected for suggestions (42\%) complaints (40\%), and apologies (18\%) in 17 EFL course books. 